\title{
Differences of Style between English and Arabic Political Discourse: A Contrastive Study Shifaa Hadi Hussein
}

\section{Translation Department- College of Arts - Tikrit University} shifaahissein@gmail.com

\author{
DOI: https://doi.org/10.36231/coedw/vol30no4.15
}

\author{
Received 1/11/2019 \\ Accepted 3/12/2019
}

\begin{abstract}
Traditionally, style is defined as the expressive, emotive or aesthetic emphasis added linguistically to the discourse with its meaning is the same. In the current study, however, style is defined as the linguistic choice that the language users can make for specific purposes.

This study, thus, aims at analyzing political Arabic and English speeches to find out whether there are differences of style between English and Arabic and whether the choices the language users make can show any traits of their psychological status.

To fulfill the above aims, the study hypothesizes that English and Arabic speeches can be analyzed stylistically and that there are stylistic differences between English and Arabic.

Two political speeches have been selected to be the data of this paper. The first is an Arabic one by the former Egyptian president Jamal Abdul Nasir. The second is an English one by president David Johnston, governor of Canada.

The model adopted here is an eclectic one. Style, according to this model, is defined as the choice the language user made at two axes; direct and indirect. The direct choice is determined relying on the theory of systemic functional grammar. At the indirect axis choice, the traditional approach of style is adopted.

The study comes to some conclusions the most important of which is that language users utilize unconsciously linguistic choices to express their points of view and intentions which say a lot about their psychological status and thus their characters.
\end{abstract}

Key Words: Arabic discourse, choice, English discourse, psychological status, style

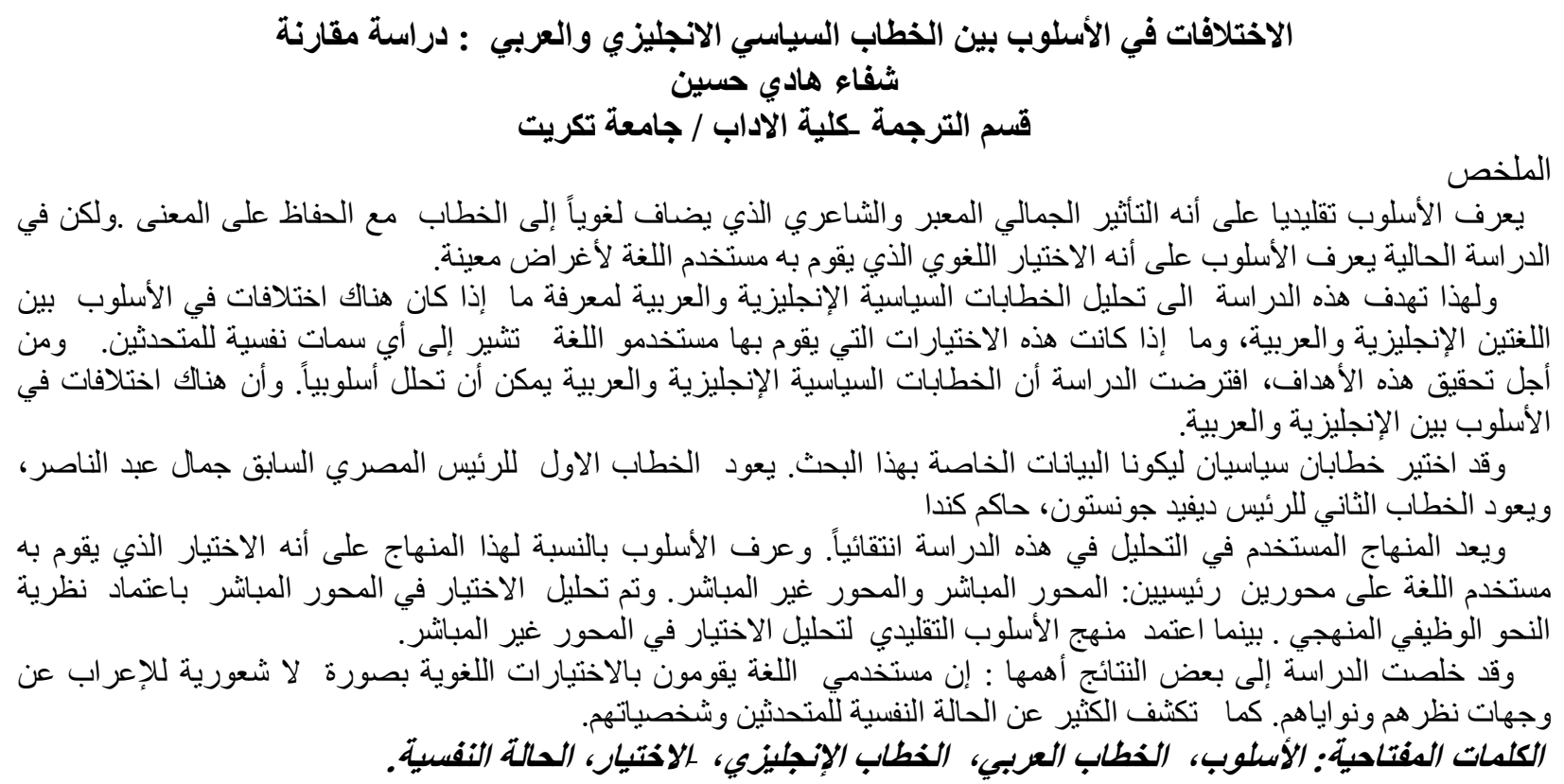




\section{Introduction}

The study of style, as a discipline, has a great role to play in handling discourse analysis. There is a close connection between the two terms in the sense that the former can provide the latter with suitable devices of analysis and, thus, can reveal the hidden intentions and the speaker's psychological status in the language used. In other words, studying style could be a means of doing discourse analysis to reveal its ideological, social, psychological as well as aesthetic dimensions. Accordingly, style is not limited to the study of the beautiful decoration of language in literary texts, but it can be used as a means to explore different dimensions in any genre of discourse being literary or non-literary ( like the one suggested in this paper). This is the intention behind writing this piece of work. Thus, non-literary discourse has been chosen as data for speculating style in relation to discourse analysis.

Style is not seen here as a matter of using beautiful constructions for the sake of providing an aesthetic effect in the discourse. Rather, it is seen as a matter of choice that the speakers utilize for specific emotional, psychological, or ideological purposes. Further, it is not a matter of deviation from the norm, but the configuration of that norm from a different perspective and for specific functions.

\section{Style}

Etymologically speaking, the word 'style' (derived from the Latin 'stylus') means a sharp stick made of metal, wood or bone used for writing on wax tablets. Then, the word is extended to include a way or a manner ( Gregorious, 2014, p. 8). Accordingly, different definitions are set for the term style. Rhetorical stylistics, for instance, defines style as the decoration added to a message (cf Enkivist, 1964), while structural stylistics defines it as " the sum of linguistic features that are considered as a characteristic of a particular text " (Gregorious, 2014, p. 19 and see section 3 in this study). Riffaterre (1959, p. 155) considers style to be " the expressive, emotive or aesthetic emphasis added, by the linguistic structure, to the information keeping the meaning " and having an emotive consequence on the readers. Halliday (1971), on the other hand, believes that style is a significant choice in specific contexts for a specific function. Also, Enkvist (1964) defines style as the choice between alternative expressions, as a deviation from the norm, as a collection of individual characteristics, and as matters of variations and recurrence (for other definitions see, Leech and Short, 1981, Butler, 1985 and Lehtsalu et al, (1973) among others) .

In this study, the following definition of style is adopted. Style is seen as the 'choice' that the language user selects from a variety of choices available in the language in a continuum of recurrence for expressiveness. Accordingly, the recurrence of choices that the speaker makes is supposed to reflect the specific psyche of the speaker and elucidate specific response from the hearer who is supposed to be affected by the speaker who uses these specific choices for the sake of persuasion.

\section{Stylistics}

Stylistics, generally speaking, is the systematic "study of style" ( Leech \& Short, 1981, p. 13) and as a discipline. It can be defined as the description and analysis of different linguistic forms in language use. It is " the analysis of linguistic forms and its social effects" (Stockwell, 2006, p.3). Widdowson (1975, p. 4) defines stylistics as " the study of literary discourse from a linguistic orientation" limiting, thus, stylistics to be within literary language, while Verdonk (2002, p. 4) defines it broadly as " the analysis of distinctive expressions in language and the description of its purpose and effect ", limiting, thus, stylistics to a set of devices.

As these definitions show ( just like many others), the term stylistics is mostly related to two terms: literary language and linguistic forms. However, stylistics cannot, in any case, be related 
to only literary language since the last is only one genre of discourse, and if stylistics is capable to find out principles for literary language, which is almost a reflection of reality, it could be used to analyze other genres of discourse-which express reality. This paper is an attempt to find out whether or not such a claim can be proved.

The roots of stylistics go back to the Greek and Roman's " Rhetoric", specifically the influence of Aristotle's term " elocution"; i.e. "the selection of style for an appropriate effect" ( Stockwell, 2006, p. 3), concentrating thus, on the term " context" to be a vital element in such a selection. In this era, the emphasis was on written texts and the purpose was to teach orators how to pick specific styles for elegant speeches. This view flourished in the $5^{\text {th }}$ century $\mathrm{BC}$, when rhetoric was considered a dominant art for the purpose of persuading the listeners to change their opinions of a specific topic (see Gregorious, 2014, p. 1). This orientation is realized then as ' rhetorical stylistics' (ibid).

As noted by Taylor (1980), it is the German and Geneva linguist Charles Bally (1865-1947) who was the first to put the systematic considerations of modern stylistics in the $20^{\text {th }} \mathrm{C}$. This linguist depends on the Saussurian tradition of formalism to develop stylistics in the shape that we realize nowadays. In this regard, Bally believes that " stylistics explores the linguistic forms in relation to their expressive and emotional points of view ( see Bally, 1909; Taylor, 1980, p. 23). Such a relation can be found in the linguistic choice the writer makes to achieve such a successful relation and thus, the concept of 'choice' plays a vital role in Bally's approach ( see Ducrot \& Todorov, 1979). This orientation is later on called ' expressive stylistics' (see Gregorious, 2014).

Depending on Bally (1909), the French stylistician Spitzer (1948) built his approach to concentrate upon the "habitual uses and choices made by the authors" concentrating, thus, on finding the psychological status of the authors being realized in their stylistic choices. He established the relation between " the style of the literary work and the psyche of the author" (Spitzer, 1948, p. 25). This trend is realized as ' psychological stylistics' ( ibid).

As a distinctive discipline, stylistics appeared in Russia in the 1960s by scholars who belong to Prague school including the Russian structural linguist Jakobson, the student of Ferdinand de Saussure. Here, stylistics emerged as a set of rules and conventions to analyze literary texts ( Stockwell, 2006, p 4). This trend is later on called ' structural or formalistic stylistics'( Gregorious,2014, p. 5-6). Jakobson (1960) concentrates upon finding the relation between the linguistic forms and literary language and how stylistic devices crystallize themselves in linguistic forms in this literary language specifically the poetic one. Here, only the text is considered, away from any other considerations like the social, historical, ideological, biological or psychological ones. In other words, only the textual features are analyzed to handle stylistics (ibid , 87). The 'functional stylistic' trend was elaborated in the 1970s by M. Halliday, (1971) and his 'systemic functional grammar' (henceforth SFG) who also considered the concept of choice to be central in his approach to study literary language to be related to specific context and specific function (whether ideational, interpersonal or textual) (Gregorious, 2014, p. 11).

There are other kinds of stylistics which limitations of space and time here prevent us from discussing them in detail. Included here are Atkins' 'individualistic stylistics' (1952) which depends on Cicero's concept of style as an " expression of personality" (Atkins, 1952, p. 31), ' new critical stylistics' ( see Riffaterre, 1959), 'pedagogical stylistics', 'historical stylistics' , 'corpus stylistics' ( Wynne, 2005; Norgaan, Montoro, \& Busse, 2010, p. 6), 'cognitive stylistics' , 'feministic stylistics', and 'multimodal stylistics' (where different theories and models are used to analyze the text ( see Gregorious, 2014).

As we can see from above, three disciplines have shaped stylistics throughout decades of time. These disciplines are rhetoric, literary criticism and linguistics. Each one of these approaches represented above tackles stylistics from a specific perspective. Rhetorical stylistics, 
on the one hand, takes the author to be ultimate in the consideration of stylistics. -However, Reffaterre (1959) takes the reader to be the ultimate goal to consider, but the structural linguists take the text to be the most important to consider. On the other hand, some approaches concentrate on the psychological aspect of the text (like Bally's, 1909) while others concentrate upon the textual aspects (like Jakobson) and others on the functional aspects of the text (like Halliday,1971).

However, due to the possibility of finding different theories and models to be involved within stylistics, we consider stylistics to be both multidisciplinary and multidimensional. It is multidisciplinary because different disciplines, theories and models can be used to handle stylistics in texts and it is multidimensional because different dimensions can be considered in the analysis of texts stylistically including lexical items, syntactic constructions and textual configurations (cf Gregorious, 2014).

\section{The Arabic Concept Style and Stylistics}

In Arabic, the notion of stylistics is not a recent one but mostly attached to the ancient Arabic rhetoric. However, Arab scholars define stylistics as the study of literary style and specifically the rhetorical study of style ( see Al-Atbi, 2012, and Al-Shehan, 2012). But, as a term, the concept of stylistics as a discipline has not gained that great attention till the middle of the last century (although the term 'style' is very old in the ancient Arabic history) due to the effect of the Western realization of the notion ( see Al-Atbi, 2012, p. 1; Ayyashi, 2002, \& AlShehan, 2012).

Etymologically speaking, the term style in Arabic refers to the 'art' ( Al-Jahid, 1968), or "the way speech gets out" ( Ibin Manzuur, 1988). Al-Masdi, (1977) defines style as " the way Arabs used to have meanings in accordance with context and so variations in style are related to different situations, the subject matter and the speaker's ability" ( my translation). Still, the term style is mostly seen as the aesthetic value that can be found in the literary work (Abdul Jaleel, 2002, p.107).

Accordingly, the term stylistics is defined as " an abstract analytic analysis aiming at finding objectivity in a linguistic field through a logical approach which uncovers the (author's) prints that make the linguistic behavior a kind of horizontal paradoxes" (Al-Masdi, 1977, p. 33 , my translation). Ayyashi, (2002, p. 2), on the other hand, relates stylistics with discourse analysis defining the former to be " a science which studies language within the system of discourse. It is, also, a science which studies discourse according to the genres of discourse. So, this science is of different levels, of different interests, of different purposes, and of different directions " ( my translation).

Still, there are other Arab scholars who are affected by the western conception of the terms stylistics and style including for instance Fadhil,( 1998 ) who seems to be affected by Enkvist's (1964) definition of style. However, as shown above, style in Arabic tradition is defined as the art of choosing specific elegant or decorated expressions to be added to the message (specifically literary ) for some aesthetic purpose. The term 'style' has been studied-in association with rhetoric ( with its three sciences: Al-Maani ( the science of meaning), Al-Bayaan ( the science of tropes), and Al-Badee' ( the science of rhetorical schemes).

\section{Political Speeches}

There are four main characteristics of political speeches; trust, truth, timing and passion( Geiger, 2016). Khoury (2019) believes that there are some other characteristics that political speakers should have to be effective: confidence, authenticity, passion, being oneself, practicing, speaking in a natural voice, being short and sweet, connecting with audience and painting a picture (metaphorically) through storytelling and repetition ( see also Drjim, 2011).

In his article, Stepanyan (2015) tries to relate good political speeches with aesthetic stylistics concentrating upon the traditional devices that can be found in books of rhetoric. He 
believes that since political speeches have a role to play in changing minds, politicians have to make use of these stylistic devices due to their power in persuasion. These devices include metaphor, alliteration, parallelism, euphemistic constructions, and etc.. He comes to the conclusion that political speeches should have these devices if they intend to be persuasive and that they differ in English and American speeches.

In the same vein, Kulo (2009) analyzes two political speeches taking into consideration the following traditional stylistic devices : metaphor, metonymy, analogy, repetition, antithesis as well as some other linguistic devices like the use of pronouns, and the system of voice. However, his study does not depend on specific model. Still, his work can be considered to some extent a stylistic study of nonliterary work.

However, characterizing a political speech as persuasive is not a matter of imposing specific characteristics of the discourse to have a good speech with a persuasive impact on the audience's mind. Instead, finding a persuasive political speech should be conducted on the basis of what the speaker has done to have his speech being persuasive. So, 'what does the speaker can do and has done?' is what matters here to analyze and not ' what is there in the discourse?'. In this sense, instead of trying to pick up some stylistic devices from here and there, we should concentrate on the choices that the speaker has and has not done at the moment of speaking. Whether the speech is persuasive or not, good or bad is not we to decide but it is the audience who is (or is not ) going to be affected by this political speech.

\section{Systemic Functional Grammar (SFG)}

SFG has been developed in the 1960s mainly by Halliday ( see Halliday, 1961; 1967; 1970 $\& 2014$ ). In this theory, language is seen as a matter of choice among alternatives ( see Halliday, 2014 , p. 20). Language is, also, a social activity of some meta-functions including ideational ( to express the experiential level of language), interpersonal ( to express the relations among the participants involved in the speech activity) and textual ( to express relations between parts of the linguistic activity) ( see Halliday, 2014, p. 30).

At each pattern (or each level), there is a choice made in contrast with what has not been chosen to signal differences in meaning referred to as " the axis of choice" or the vertical paradigmatic axis ( in contrast to the horizontal syntagmatic axis which refers to the patter )( see Berry, 1977 , p. $3 \& 1975$, p. 54). So, the notion of choice is very important to SFG since the main task of the latter is to " discover what options are possible at each level of language and to show how they contrast along the axis of choice " ( Berry, 1977, p. 30). Also, the task of SFG is to relate these choices to the functions that the linguistic activity intends to make ( see Butler, 1985, p. 197). To study these choices, systemic functional grammarians rely upon the notion of system with units of grammar (e.g. clauses, groups and etc.) to be the entries of these systems. The term 'system' can be defined as " a list of choices which are available in the grammar of a language " ( Berry, 1975, p. 142). It is, further, a " list of things between which it is possible to choose....these things are meanings" (ibid, p. 143), meanings among which the language user can distinguish. These systems include transitivity ( material, mental and behavioral processes, participants and circumstances), tense (past and present), number (singular and plural), person (first, second and third), voice (passive and active), mood (declarative, imperative, and interrogative), and modality (necessity, possibility, willingness, and obligation )systems ( see Berry, 1975, p. 52 ; Halliday, 2014). Within the transitivity system, different processes are associated with different participants: with the material process, the participants could be actor, goal, beneficiary or range. Within the mental process, the participant could be sensor or phenomenon and with the relational process, , the participant could be Token, Value, possessor or possession.

\section{The Relation between Stylistics and Systemic Functional Grammar}


The relation between stylistics and SFG is not a recent one and goes back to the 1970s when some scholars develop SFG relying mainly on literary stylistics (see Butler, 1985, p. 198). Halliday, for instance, tried to apply SFG to literary work with the help of stylistics ( see Halliday, 1971). In his study, Halliday applies the linguistic choices Golding has made in his novel The Inheritors to achieve his goal in representing meanings. Specifically, Halliday concentrates upon the transitivity system's choices that the writer has made for the sake of meaning.

Similarly, Kennedy, (1976) applied SFG to literary work when he applies this theory to concentrate upon the role of participants in the literary works he selected. In his article (1976) " Systemic Grammar and its Use in Literary Analysis", Kennedy examines the roles of the participants in two passages from two novels; the Secret Agent by Conrad and "Dubliners" by Joyce.

In the same way, Burton , (1982) uses also the transitivity system to analyze a passage from the Bell Jar by Sylvia Plath to concentrate on both the processes and the participants ( for similar studies, see Norgaard, 2003, Goatly, 2004 and Iwamoto, 2006).

As noted from the above studies, it seems that these studies share some common features which are : considering stylistics to be a discipline more related to literary studies than to other genres of discourse. Also, it seems that the transitivity system is the most common system to use in analyzing the data chosen.

In this study, however, stylistics is not viewed as a literary study or as a discipline concerned with literary works, stylistics is seen to be a comprehensive discipline which can be applied to any genre of discourse whether spoken or written, literary or non-literary. It is the discipline of the choice that the language user has at any level of language and in any genre of discourse whether consciously or unconsciously.

Here, two levels are going to be selected for the analysis, directness and indirectness levels. Directness level will be studied according to the choices that the speaker makes and this is going to be handled in accordance with SFG. The indirectness level is going to be handled in relation to rhetorical choices available to the language user. And here, Lehtsalu, Liiv, and Mutt, (1973) and Qassim and Deeb, (2003) models will be adopted.

The choices at these levels are expected to be conducted to fulfill specific functions and objectives that the language users want to convey being expressive, persuasive, social , ideological and etc.. However, mostly these choices reflect the speaker's psychological aspects in the linguistic activity. In this sense, this study is hoped to be social, psychological as well as discursive in nature.

Accordingly, this study relies on SFG, Aristotle's conception of style (being represented in his 'rhetoric'), the Arabic rhetoric and its three sciences ( although concentration is going to be on tropes and schemes only) and Leo Spitzer' conception and approach of stylistics. Thus, three types of stylistics are represented here; functional stylistics, aesthetic stylistics and psychological stylistics respectively.

\section{The Chosen Data}

The data chosen in this paper constitutes two parts. The first part is a political speech of the former Egyptian president Jamal Abdul Nasir on 19 ${ }^{\text {th }}$ July, 1957 in Al-Jumhuriyya Square to celebrate the Day of Evacuation. Here, the president was talking about the revolution and its objectives (which include getting rid of colonization, feudalism and monopoly, having social justice, finding the powerful army, and finding a democratic life). The second part is a political speech by president David Johnston, governor-general of Canada, on $4^{\text {th }}$ of December, 2015 to open the $1^{\text {st }}$ session of the forty-second parliament of Canada. This speech is about the reforms that the government of Canada intends to establish through the year of 2015. 


\section{Methodology and Data Analysis}

The methodology adopted in this paper is going to be as follows: first, due to a large amount of data selected, only some stretches of the data are going to be analyzed. These stretches are selected on the basis of their relevance to the approach developed in this study. Second, depending on this approach, the data are to be analyzed in accordance with the linguistic phenomenon detected whether it is direct or indirect. Within the direct choice, Halliday's theory of SFG is going to be applied. Accordingly, the choices that the speakers have conducted are from the transitivity, voice, mood, modality, number, person, and tense systems. While within the indirect choice, Lehtsalu et al 's (1973) and Qassim and Deeb's, (2003) models are going to be applied. The indirect choice is going to be handled in each language separately due to the exclusivity of the language as far as this choice is concerned. So, terminologies are kept for each language, although sometimes there are some similar points between the two terminologies in the two languages like the cases of metaphor and 'istiaara, metonymy and kinaaya, quotation and 'iqtibaas, antithesis and tibaaq (in cases of single lexical items), parallelism and mura'aatu 1nazeer and muqaabala and antithesis ( in cases of sentences).

\section{A. The Arabic Discourse}

Throughout his speech, president Abdul Nasir tries to establish two worlds; the one before the revolution and the one after the revolution. In representing the world before the revolution and the evacuation, president Abdul Nasir shows this world to be a black one where feelings of injustice and slavery are prevailing everywhere in Egypt. But, the present day after the evacuation is shining and is characterized by feeling of freedom. These worlds are clarified in the discourse selected from the discursive choices that the speaker has utilized in his discourse. These choices are going to be analyzed in what follows.

Within the direct choice, president Abdul Nasir has made use of the two kinds of tenses; present and past. The old world is always described by the past tense. Consider the following examples taken from the data :

1. كنا ننادي بالحرية وننادي بالاستقلال, أحاسيس ورثناها جيل عن جيل..........كان سننا صغير ماكناش نعرف المعاني

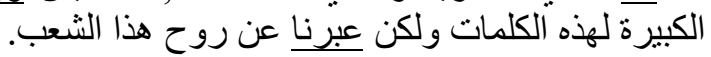

(We were calling for freedom, and calling for independence, feelings that we inherited from a generation to another,..... we were so young that we did not know the great meanings of these words but we expressed the spirit of this nation.

2. النهاردة بااخو اني نشعر جميعا ان الهدف قد تحقق.

( Today, brothers we all feel that the objective has been accomplished).

In example (1), the tense used is past to express the old world. While in the second example , the present tense is used to show the present world after the evacuation.

In order to convince his audience of electing him again as a president and keeping the objectives of the revolution, president Abdul Nasir relies heavily on the third persuasive strategy of Aristotle ; i.e. pathos ( or the emotional appeal) although his speech fulfills the other two conditions of being persuasive ; i.e. logos ( using rational argumentation) and ethos ( being reliable and credible). Mostly, president Abdul Nasir depends on this strategy to convince his audience by the discursive choice from transitivity system. He first made use of the mental process in his speech combining,thus, himself with the audience. Consider the following examples:

$$
\text { 3. النهاردة بااخو اني نشعر جميعا ان الهدف قد تحقق , لقد قضي على الاحتكار. }
$$

(Today brothers, we all feel that the objective has been accomplished, the monopoly has been eliminated).

(I think that today we feel that we are masters in this homeland.)

$$
\text { 4. و انا اعتقد اننا اليوم شعرنا بانا اسياد في هذا الوطن. }
$$


5. كنا بنادي بهذه الالفاظ , الفاظ الحرية , وماكناش نعرفها , وماكناش حاسيين بيها, ماكناش شفناها, اتولدنا في عهد الاحتلال

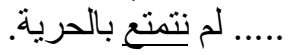

(We were calling for these expressions, expressions of freedom, and we had not known them, we had not felt them, we had not seen them, we were born in the era of occupation..... we had not enjoyed freedom.)

The underlined processes are all mental which are used to persuade the audience and affect their emotions to keep the gains of the revolution by sharing with them feelings of freedom.

Second, most of the participants involved in the discourse ( except the inclusive 'we' and 'I' ) are inanimate. They include nouns like freedom, revolution, objectives, democracy, constitution, homeland, our policy, and etc.. These participants are mostly combined with the material processes and they have the roles actor, range and phenomenon. Animate participants (including inclusive 'we' and 'I ' ) are mostly associated with mental processes and they are of the type sensor.

$$
\text { 6. قامت الثورة وكانت تهذف الى القضاء على الاستعمار. }
$$

actor participant / Material process

( The revolution took place and it aims to get rid of the colonization).

7.تخلصنا من الاحتلال الاجنبي. range participant / Material process

(We has gotten rid of the foreign occupation).

8. phenomenon participant / mental process / Sensor participant

(I feel of freedom.)

But it should be noted here that actions in president Abdul-Nasir's speech are never directed to anybody and, thus, there is seldom any animate participants with the role of goal. It indicates that the speaker decides to choose to hurt or affect no one in his speech but to win hearts. He is threatening no one but trying to convince his audience that they should stand with him to protect the revolution.

The circumstances involved in this discourse is mostly temporal. By this specific choice president Abdu-Nasir was able to compare between his two established worlds, being represented by the temporal circumstances (في الماضي , النهاردة, اليوم) (in the past, today, today) and etc.

$$
\text { 13. و اخطب فيكم من } 23 \text { يوليو ولغاية البارحة.... كنت احس ان هنالك ثقلا على قلبي. }
$$

(And I orate since 23 ,July till yesterday... I felt that there is a ballast on my heart.)

$$
\text { 14. اما اليوم فقد اختلفت الظروف والاحوال فلا يرفرف علر مصر سوى علم واحد. }
$$

(Today, circumstances are different, there is only one flag which is flitting on Egypt.)

These circumstances have been repeated so frequently in the discourse selected. They crystallize the two mentioned worlds in order to concentrate on them and let the hearers pay attention to them to keep the present world and never let the old one return back.

Furthermore, the Egyptian president expresses meanings of detachment and inclusiveness through the utilization of number and person systems. Mostly, he used the inclusive 'we' / 'us' in his speech when he wants to refer to himself. Inclusion of himself within the audience gives the speaker the opportunity to have his audience's trust since he is becoming one of them having their rights and obligations. The speaker used only the first person singular pronoun 'I' or even his proper name when he talked about the election and his principles which he intends to keep after the election to detach himself from the current government ( rather than people) and to give the impression that he is responsible for his partners' actions in the government no more. Consider the following examples:

(We are talking about establishing social justice.)

$$
\text { 9. احنا بنتكلٍ عن اقامة عدالة اجتماعية. }
$$




$$
\text { 10. اذا كنا عايزين نقضي على الظلم الاجتماعي.....ونقيم مجتمع تسوده الرفاهية ...... لازم نعمل. }
$$

(If we want to get rid of social unfair....and establish a world where luxury prevails in, we have to work.)

$$
\text { 11. جمال عبد الناصر في يوم من الايام قال لهذا الثعب انا لن اخذلكم. }
$$

(One day, Jamal Abdul Nasir told this nation " I will not let you down").

(These are, brothers, the principles that I believe in.)

$$
\text { 12. دي ياخو اني المثل اللي انـا بؤمن بها. }
$$

Within the mood system, president Abdul Nasir chooses the declarative mood. All the sentences are declarative, no imperative or interrogative sentence is found in the whole discourse. It proves that the speaker is informative, direct, confident, and sure of himself and whatever is said is not in a position to be questioned whether by himself or by the audience. Everything is straightforward, clear and has the sense of credibility. Also, what is referred to is logically managed in the sense that the discourse is rationally represented by the use of numeration sometimes and by chronological order some others as shown in the following examples :

13. قامت الثورة وكانت تهدف اول ماتهدف الى القضاء على الاستعمار .....وكنا نهذف ثانيا .... الى القضاء على الاقطاع..... (The revolution took place and it aimed first to get rid of colonization......and we aimed second.....to get rid of feudalism...)

$$
\text { 14. في سنة } 1930 \text { ثار الثعب كان بيطالب بحريته....سنة } 1936 \text {.....نفس القصة تكررت هنا في القاهرة........................ }
$$

( In 1930, the people revolute and they demand their freedom...in 1936...the same story was repeated here in Cairo.)

The Egyptian president expresses his confidence and his strong commitment to what is said by the choice of the modality system that prevails almost all over the speech. The speaker chooses the sense of necessity modality to be expressed in his speech as represented in the following examples:

$$
\text { 15. هذه هي المثل اللي انا بؤمن بها والتي لايمكن ان احيد عنها. }
$$

( These are the principles that I believe in and that I will never deviate from.)

( We have to cooperate.)

$$
\text { 16. يجب ان نتعاون. }
$$

( No matter how I worked alone, I will never be able to work alone .)

$$
\text { 17. مهما عملت انا لوحدي مش حقدر ابدا. }
$$

(We have to walk very fast .)

$$
\text { 18. لاز مُ نمشي بسر عتين. }
$$

(Every benefit should be for the homeland as a whole.)

$$
\text { 19.كل فائدة لازم تعود على الوطن ككل. }
$$

In all these examples and in many others, the sense of modality used here is that of necessity and obligation. This indicates that the former Egyptian president is sure of what he is saying, has confidence in himself and his audience and believes in what he is saying. These senses of modality are expressed by the choice from the modality system conducted by the use of the verbs ( يجب, لازم = يجب , لايمكن ) ( have to, must, never) and the intensifier (ابدا) (never).

The other system referred to here is that of voice. It is noticed that all the sentences used in the president's speech are active. No passive sentences are ever shown here. If this proves something, it proves that president Abdul Nasir is ready to hold the responsibility of everything said. There is nothing and nobody to hide. He is afraid of nothing and nobody and he declares his sentences actively and clearly.

In a second look at the data chosen here, we can see that president Abdul Nasir has chosen some indirect devices to illustrate his meanings and to convince his listeners of what he is saying. Let us consider the following examples:

$$
\text { 20. لقد مر حين من الدهر ونحن نجاهد. }
$$


( So long time elapsed while we are fighting.)

The underlined expression is a choice of 'iqtibaas (quotation) (the use of quotations from the Glorious Quran , Al-Hadeeth Al- Shareef, from classic poetry or orations) ( see Qassim and Deeb, 2003: 127) that the speaker utilizes to strength his discourse. This 'iqtibaas has been taken from the Glorious Quran from the verse :

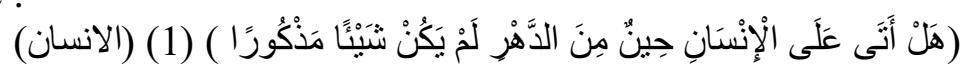

(Surely there has come upon man a space of time when he was not a thing worth mentioning) ( Daryabadi,2004, p. 394).

to refer to a very long period. The use of such a quotation adds a sense of credibility to the discourse at hand.

21. وكان اباؤنا بتجاهد...... من اجل حقهم في الحياة, من اجل حقهم في العيش الكريجر, من اجل حقهم في العدالة وفي الحرية وفي المساو اة.

( Our fathers were fighting.... For their right of life, for their right of bounteous living, for their right of justice, freedom and equalization.)

In the preceding example, the underlined expressions represent the use of mura'atu- nazeer (parallelism) ( which refer to the use of almost similar expressions in meaning which are combined with each other)( see Qassim and Deeb, 2003: 91). The expressions , العيش الكريم , العدالة ( bounteous living, justice, freedom, equalization ) are all combined by the repetition of the use of (من اجل حقهم) (for their right) to give almost the same meaning; i.e. 'beautiful life'.

Cases of tibaaq (antithesis) (which is the combining of two lexical items in the same sentence )( see Qassim and Deeb, 2003: 65) can be found in this discourse. Consider the following examples :

(We get out of tribulation to fall into another one.)

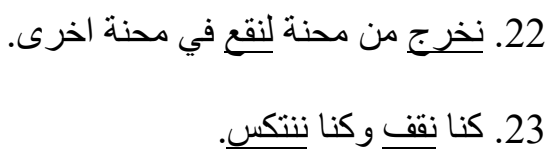

(We had stood and we had relapsed.)

In these two examples, the underlined words are representing two contradictory meanings that the speaker wants to express to give his audience the chance to think and consider these meanings carefully and to let them share him his mental process of how to think of old times.

Also, cases of saja' (assonance/consonance)( which is the repetition of the last letters of two or more successive words) (see Qassim and Deeb, 2003: 106) can be realized in the data selected. Consider the following example:

(And to keep its morals and to keep its nationality.)

$$
\text { 24. و ان يحافظ على معنوياتهِ وان يحافظ على قوميتِ.. }
$$

The repetition of (ته) (its) at the end of two words in one sentence marks a case of saja' to create a case of harmony difficult for the hearers to forget later on.

In the following example, a case of muqaabala (antithesis in sentences), where two contradicting sentences are represented, (see Qassim and Deeb, 2003 , p. 72) is represented:

25. ان هذا الشعب كان يهب ويكافح ويناضل ويستشهد ويقاتل, وكان بعد هذا يسكن ويسكت ويلاقي الذل و المحن سنين طويلة. (This people were rushing, struggling, fighting and being martyr and then, calms ,hushes, and meets humiliation and tribulations for many years.)

The two underlined sentences represent two contradictory states of the Egyptian people prior to the revolution, a portrait that is represented in front of the hearers to see how their nation was in the past when people once fight and then humiliated but still it is patient in order not to lose its hope of freedom.

Also, there are many cases of ?isti'aara (metaphor) ( which is the adaptation of one single meaning from many to be used without mentioning the phases of difference between the source (from where this meaning has been taken) and the target ( the referent referred to by this 
meaning)(see Qassim and Deeb, 2003: 192) can be found here. Consider the following examples:

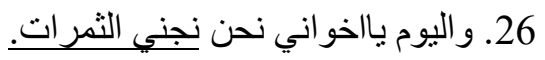

(And today, brothers, we harvest the fruits.)

$$
\text { 27. نحن نبدا فجر حياة جديدة ترفرف عليها نسائم الحرية. }
$$

(We start a dawn of a new life which breezes of freedom flit on.)

(The dawn which had broken yesterday when the Egyptian flag flits....)

$$
\text { 28. ان الفجر الذي انبلج بالامس حينما ارتفع العلم المصري................ }
$$

In these examples, evacuation is metaphorically shown as

( نجني الثمرات ,فجر , انبلاج الفجر ( we harvest the fruits, dawn, breaking of the dawn) in an attempt to show the evacuation as something beautiful which starts a new day and a new life for the Egyptians. Also, freedom is represented as having breezes to show that freedom has beautiful and clear air that everybody would like to smell. Hearers are invited with president Abdul Nasir to experience this beautiful feeling of freedom.

Cases of kinaaya (metonymy) ( which is a lexical item where two meanings can be found, both are acceptable in the interpretation of the text, but one of them is deeper and it is more likely to be intended)( see Qassim and Deeb, 2003: 241) are also detected in the president Abdul Nasir's speech. Let us consider the following example:

(Egypt has always been a cemetery for the tyrants).

29. كانت مصر دائما مقبرة للطغاة.

Two meanings can be realized from the word (مقبرة) (cemetery), the first is the actual meaning and the sentence is understood to have the meaning : Egypt is always actual cemetery for the tyrants to bury them, and the second is metaphorical and the sentence is understood as : Egypt is the end point of the invaders where invasion stops there forever. This is the intended meaning.

\section{B. The English Discourse}

throughout his speech, president David Johnston tries to build only one world which is that of the present. This shows that the speaker is directing his audience to see only one world which is that he and his government intend to build. His audience, here, are passive and deprived from having any role to play in building that world. There is no emotional contact between the past and present that the speaker might share with his audience. This fact is crystallized in the choices the speaker made from transitivity system and tense systems.

In a deep look at the English discourse selected, the speaker seems to choose only one tense which is the present. Past tense is never used as shown in the following examples:

31. The government is committed to providing greater security.

32. Canada is a .....safe and peaceful country.

It seems, also, that the president has chosen the three types of processes in his speech (material, mental and relational) but mostly he depends on the material process to express his ideas as shown in the following examples:

30. A warm welcome to those of you who are returning to your duties.

31. The government can make real changes.

Depending more on the material process indicates that the speaker relies on rationalism and logic rather than emotions to express his ideas. In other words, he is calling for minds rather than hearts to convince his audience of his point of view.

Mostly, the participants used in this discourse are inanimate like Canada, parliament, government with the roles actor, goal, and beneficiary as in :

32. The government will promote more open debates,
Actor participant
goal participant

33. To give Canadians a more secure retirement, the government will actor participant 
work with the provinces.... to enhance the Canada Pension Plan.

This realization perhaps proves that the government (which mostly has the role of actor in this discourse) is the only active power and the doer of the action. This gives us the indication of tyrant that no one else in the discourse has the role of being an actor but the government.

Furthermore, it is realized strangely that this discourse almost lacks spatio-temporal circumstances. The speaker makes use of only some intensifiers as a kind of circumstances like ( well, especially, more, fully, and etc.).

34. The government will strengthen its relationship with allies, especially with the closest friend ....USA.

35. Your enthusiasm .... will serve your country well.

This choice can be justified by the fact that the speaker has already detached himself from his audience in place and time. And so, this detachment is crystallize in his rejection of choosing the spatio-temporal circumstances to be away in place and time.

As far as the number system is concerned, the speaker in this discourse has mostly used the third person singular to refer to himself being a representative of the government. The pronouns I $\backslash$ we, thus, are rarely used. This, again, indicates that the speaker detached himself away from his audience giving the power to be of the government and to no one else.

As realized in the discourse, it seems that the president David Johnston chooses the passive voice in many cases:

36. Welcome, also, to the 197 members who are newly elected.

37. All members will be honored, respected and heard.

38. Diverse perspectives and different opinions are celebrated not silenced.

39. Public investment is needed.

In all these examples ( and many others), the governor chooses the passive voice to express his point of view to his hearers. Hence, he has expressed (unconsciously) the idea that he is irresponsible for what is said and he is not involved in the processes expressed in each sample. So, instead of saying " I will honor, respect, hear" to hold the responsibility of the action, the speaker deviates such a responsibility to somebody else (or others) but not himself (or may be not only him) and the same is true for the other samples.

As the mood chosen, the Canadian president decides to have his discourse being in declarative mood; no interrogative or imperative sentences are detected. This choice indicates that the speaker is sure of himself and what he is saying is never questioned or suspected by anyone because he believes in what he is saying.

As far as the choice of modality is concerned, it seems that different senses of modality are expressed in this discourse. In the following samples, president David Johnston declares the government's ability to do things.

40. The government can make real changes.

41. The government can meet these challenges.

However, mostly, the modality meaning expressed in this discourse is that of willingness expressed by the modal verb 'will'. This meaning has been represented widely in the discourse as shown in the following samples:

42. Your fresh ideas will serve your country.

43. The government will work .....to make post-secondary education more affordable.

According to these examples, the speaker chooses this sense of willingness to promise his audience to do these reforms that he is talking about. Instead of expressing certainty, possibility, or necessity of establishing these reforms, the speaker chooses the ' willingness' sense to express his ideas; i.e. the governor is willing to do that but whether certain or not, nobody knows and whether possible or necessary, also nobody knows. 
Across the axis of indirectness, president Johnston has chosen some little devices in order to express his ideas as represented below:

44. Know that your experience is valued.

In the previous example, a case of aposiopesis ( the use of incomplete sentence which is understood by others) ( see Lehtsalu et al, 1973, p.62) is detected because the speaker omits the subject of this sentence " you" and it is used for economy.

45. I call on all parliamentarians to work together, with a renewed spirit of innovation.

A case of personification ( where things are given human charaterstics )( see Lehtsalu et al, 1973

: 52) can be realized here since 'innovation' comes to have a spirit to talk about. Such a choice is made for sake of emphasis.

46. I have seen .... what a great country Canada is from coast to coast to coast.

The repetition of the phrase 'to coast', as indirect choice ( see Lehtsalu et al, 1973 :71-77) has been chosen to add a sense of emphasis to the sentence and to show how actually Canada is great that she outreaches different coasts.

47. Different opinions are celebrated, not silenced.

A case of antithesis is shown here since the speaker (being rhetorical) used two meanings in the same sentence (see Lehtsalu et al, $1973: 54$ ). Such a choice gives a chance to the audience to have a deep look at this sentence to see how important differences are in opinions. So, this device is selected for emphasis. Also, it should be said that these devices are used , further, for aesthetic purposes.

\section{Discussion}

As the analysis up shows, the approach adopted is applicable to both the English and Arabic political speeches. However, some differences between the two speeches are detected. President Abdul Nasir tries to build two worlds ( the old and the present) and give the audience a chance to make a conception of the two giving them, thus, the freedom to choose between these two worlds. On the other hand, president Johnston elaborates only one world which is that of the present imposing, thus, this world on his audience who are deprived from the freedom of choice but this world. Consequently, President Abdul Nasir has made use of the two tenses; past and present to create these worlds while president Johnston has chosen only the present tense to create his world.

In order to convince their audience, President Abdul Nasir has chosen to rely on the strategy of pathos, while president Johnston decides to rely on that of logos, which is crystallized mostly in the choice of the mental process ( by President Abdul Nasir) and the material process (by president Johnston).

The participants in the two discourses are inanimate having the roles of actor, range, sensor, and phenomenon in the Arabic discourse and actor, goal and beneficiary in the English discourse selected here. President Abdul Nasir made use of the inclusive pronoun 'we' in many cases to prove that he is one of his audience and one of his nation. President Johnston, on the other hand, has rarely used this kind of reference which indicates that he has detached himself from his audience.

In addition, the two discourses differ in the way of using 'circumstances'. President Abdul Nasir 's speech is characterized by the use of both temporal circumstances to justify his two worlds and differentiate between them. While president Johnston's speech is characterized by the use of intensification circumstances to emphasize the oneness of his world.

In the two discourses, the mood chosen is declarative and no examples of interrogative or imperative mood are found. This proves that the two presidents are confident of themselves, informative, direct, and sure of themselves and of what they are saying. So, nothing to doubt about, nothing to question or even suspect. 
As far as the modality system is concerned, president Abdul Nasir expresses his strong commitment to what he is saying by the choice of the 'necessity' sense of modality. While, president Johnston decided to choose ' willingness' sense of modality. This proves that the former insists on and believes in what he is saying while the latter expresses his government's willingness (not his) to do 'something' and promises his audience of doing that 'something'. And whether this something' is going to be accomplished is a question of relativity.

Furthermore, the choice of voice is different between the two discourses. President Abdul Nasir had always chosen the active voice in his sentences. Passive voice has never been found in the whole discourse which proves that the speaker here is holding complete responsibility for what is said. There is nothing and nobody to hide behind the lines. President Johnston, on the other hand, has made use of passive sentences in his discourse to put the responsibility on others' shoulders and to detach himself away from any responsibility that may be expressed in his speech.

As for the indirect choice, both speakers made use of such a choice for different purposes. President Abdul Nasir chooses the technique of quotation ( to add credibility to his speech), mura'atu l-nazeer, saja' ( to add beautiful rhythm to his speech and for emphasis) tibaaq, muqaabala, metaphor, and metonymy ( to invite his audience to be with him in the same mental process to think of what is being said). Further, he used these techniques for aesthetic purpose. While president Johnston used less indirect techniques including aposiopesis, personification, repetition, antithesis and parallelism. He has used these techniques for emphasis and aesthetic purposes.

Accordingly, President Abdul Nasir 's character seems to be more passionate than president Johnston's. Besides that, he seems to be clear, more confident, more ready to hold the responsibility, more ready to inculcate himself within his people to be one of them . He imposes nothing on his audience, but always gives them the freedom to choose among alternatives. President Johnston seems to be more rhetorical, more rationalistic, more detached from his people, unready to hold responsibility but still confident of himself. Also, he seems to be more taskmaster or despot that he imposes his government's decisions on his people.

\section{Conclusions}

Stylistics, as defined here, can be applied to both English and Arabic discourses, though the two languages differ to a large extent. Also, the approach developed here proves to be applicable to both English and Arabic. The direct axis choice proves to be applicable to-both English and Arabic when SFG is used to be the model of analysis. But when the indirect axis choice is determined, the two languages prove to be unique in their indirect techniques which is why they have been dealt with separately to conserve the uniqueness of language.

The selections made from the transitivity, mood, modality, voice, tense, and number systems prove to be done for creating specific status in the discourse and here it is the case of creating different worlds. Also, such choices reflect unconsciously specific traits of the speakers' characters. Accordingly, the stylistic approach adopted here relates linguistics to psychology. Since it is through the linguistic choices, we are able to realize some characteristics of the speakers' psychological status.

Furthermore, hidden intentions are unveiled here since relying on such linguistic choices, we are able to show the speakers' real intentions behind their discourses. In this case, stylistics bridges the gap between linguistics and pragmatics.

\section{References}


Abdul Jaleel, A. (2002). Al-islubiyya wathulathyyat al-dawair al-balagiyya. Amman : Dar Saffa.

Al-Jahid, A. (1968). Al-bayan waltabyeen. Revised by Haroon, A. , Egypt.

Al-Atbi, Z. (2012). Al-islubiyya. Retrieved from :https://zakyahll.blogspot.com/2012/01/blogspot_17.html. (pp. 1-22) 22/1/2019

Al-Masdi, A. (1977). Al-isluub walislubiyya : Nahwa badeel al-suni fi naqdi al-adab. Tunis : Al-Dar Al-Arabiyya Lilkitaab.

Al-Shehan, N. (2012). Al-islubiyya mafhuman wanadra tatbeeqiyya. Retrieved from : https: // nasershehan.blogspot.com/2012/04/blog-post_16.html.21/2/2019

Atkins, J. (1952). Literary criticism in antiquity. London : Cambridge University Press.

Ayyashi, M. (2002). Al-islubiyya watahleelu lkhitaab. Lebanon : Markaz Al-Inmaai Al-Hadaari.

Bally, C. (1909). Traitede stylistique francaise. Paris : Routledge.

Berry, M. (1975). An Introduction to Systemic Linguistics.1 Structures and Systems. London : BATSFORD LTD.

-(1977). An introduction to systemic linguistics: 2, Levels and Links . Great Britain : Billing and Sons Ltd.

Burton , D. (1982). Through glass darkly, through dark glasses. In Carter, R. (Ed.) Language land Literature: An introductory reader in stylistics. (pp.30-44) London : George Allen \& Unwin.

Butler, Ch. (1985). Systemic linguistics : Theory and application. Great Britain : Biddles LTD.

Daryabadi, A. (2004). Tafsir-uL-Quran: Translation and commentary of the Holy Quran. Syria: Dar Ibn Katheer

Drjim, A. (2011). How to write a good political speech. Retrieved from: theacidentalcommunicator.com/create/how-to-write-a-good-political-speech.1-15, $4 \backslash 3 \backslash 2019$.

Ducrot, O. \& Todorov, T. (1979). Dictionaire encyclopeique des sciences du langage. France : Routledge.

Enkivist, N. (1964). On defining style. In Spencer (Ed.) Linguistics and style (pp.1-56) Oxford : Oxford University Press,.

Fadhil , S. (1998). Asaaleeb shiiriyya muaasira. Cairo: Dar Qabaa.

Geiger, E. (2016). Political speeches and four characteristics of a great message. Retrieved from : $\quad$ https://ericgeiger.com/2016/07/political-speeches-and-four-characterstics-of-a-greatmessage/, 1-10 . 11\1\2019 
Goatly, A. (2004). A corpus linguistic, systemic, functional and literary meaning. A critical analysis of Harry Potter and the philosopher's stone. Floianopolis, 46, 115-154.

Gregarious, Ch. (2014). Stylistics and style : Concepts and theory. In Burk, M. (Ed.) Handbook of stylistics. (pp. 34-57) London :Routledge.

Halliday, M. (1961). Categories of the theory of grammar. Word, 17, 241-292.

(1967). Notes on Transitivity and theme in English, Part 2. Journal of Linguistics, 3, 199-244.

(1970). Language structure and language function. In Lyons, J. (Ed.) New horizons in linguistics. (p. 140 - 165) USA: Penguin.

(1971). Linguistic function and the literary style : An inquiry into the language of William Golding's " The inheritors". In Chatman, S. (Ed.) Literary style : A symposium (pp. 330-365) New York : Oxford University Press.

----------- (2014). Introduction to functional grammar. $4^{\text {th }}$ edition. USA : Routledge.

Ibin Manzoor, M. (1988). Lisaan al-Arab. al-muheet. Beirut : Dar Al-Jeel.

Iwamoto, N. (2006). Stylistics and linguistic analysis of a literary text using systemic functional grammar. Retrieved from $<$ human.kanagawau.ac.jp/gakkai/pdf/no162/16209>25\2\2019

Jakobson, R. (1960). Closing statement : Linguistics and poetics. In Sebeok (Ed.) Style in language . Cambridge (pp. 22-30), The MIT Press.

Kennedy, C. (1976). Systemic grammar and its use in literary analysis. MALS Journal, 1, 1738.

Khoury, P. (2019). The top characteristics of effective public speakers. Retrieved from: https ://mageticspeaking.com/the-top-9-characterstics-of-effective-public-speakers/ ,1-10, $10 \backslash 3 \backslash 2019$

Kulo, L. (2009). Linguistic features in political speeches: How language can be used to impose certain moral or ethical values on people. Unpublished Bachelor Thesis. Lulea: University of Technology Press.

Leech, G. \& Short, M. (1981). Style in fiction: A linguistic introduction to English fictional prose. $2^{\text {nd }}$ ed. London: Pearson Educational Limited.

Lehtsalu, U. , Liiv, G. \& Mutt, O. (1973). An introduction to English stylistics. London : Tartu State University Press.

Norgaard, N. (2003). Systemic functional linguistics and literary analysis. Denmark : University of Southern Denmark Press. 
Norgaan, N. Montoro, R. \& Busse, B. (2010). Key terms in stylistics. New York : Continuum International Publishing Group.

Qassim, M. \& Deeb, M. (2003). Auluum al-balaaga al-badeei walbayan walmaany. Lebanon : Al-Muaassasa Al-Hadeetha lilkitaab.

Riffaterre, M. (1959). Criteria for style analysis. Word, 15(1), 154-174.

Sheekha, M. (2016). Mabahith fi Al-islubiyya walsard. Retrieved from: www.m-aarabia.com/vb/showthead.php?!=14262. 1-9, 22\11\2018

Spitzer, L. (1948). Linguistics and literary history: Essays on stylistics : Princeton : University Press.

Stepanyan, L. (2015). Stylistic peculiarities of political speeches in English and Amerian. YSU, $12,369-385$.

Stockwell, P. (2006). Stylistics : Language and literature. Retrieved from: https://www.academia.edu/719004/Stylistics_language_and_literature.12/11 2018

Taylor, T. (1980). Linguistic theory and structural stylistics. Oxford : Pergaman Press.

Verdonk, P. (2002). Stylistics. Oxford : University Press.

Widdowson, H. (1975). Stylistics and the teaching of literature. London : Longman.

Wynne, M. (2005). Stylistics : Corpus approaches. Retrieved from : < https://researchgate.net $>9 \backslash 12 \backslash 2018$. 


\section{The Data Selected}

President Abdul Nasir, J. (1956). Speech in the popular conference in Al-Jumhuriyya square on $19^{\text {th }} \quad, \quad$ July 1956. Retrieved from nasser. Bibalex.org/Speeches/SpeechesAll.aspx?CS=1\&x=2..ar. $10 \backslash 11 \backslash 2018$

President David Johnston (2015). Speech to open the first session of the 42 parliament of Canada on $4^{\text {th }}$, December, 2015. Retrieved from: https://www.canada.ca/en/privycouncil/campaigns/speech-throne/making-real-change-happen.html. 15\12\2019. 